\title{
EFFECT OF PRE-PROCESSING ON THE PHYSICO-CHEMICAL PROPERTIES OF MORAMA BEAN (TYLOSEMA ESCULENTUM) MILK
}

\section{Mpotokwane $S^{1}$, Tlhong $\mathbf{T}^{1}$, Mthombeni $\mathrm{F}^{2}$, Gaditlhatlhelwe $\mathbf{E}^{\mathbf{1}}$, Phokoje $\mathrm{O}^{1}$ and JC Jackson ${ }^{2 *}$}

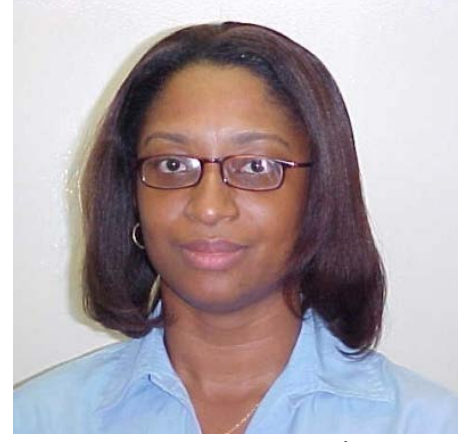

Jackson José

*Corresponding author email: jcjakson@yahoo.com

${ }^{1}$ Mr. Selalelo Mpotokwane is a Senior Food Technologist at the National Food Technology Research Centre, Private Bag 008, Kanye, Botswana.

${ }^{1}$ Ms. Tumelo Tlhong is a Senior Extension Officer at the National Food Technology Research Centre, Private Bag 008, Kanye, Botswana.

${ }^{1}$ Mr. Elijah Gaditlhatlhelwe is a Food Technologist at the National Food Technology Research Centre, Private Bag 008, Kanye, Botswana.

${ }^{1}$ Mr. Omphile Phokoje is a Food Microbiologist at the National Food Technology Research Centre, Private Bag 008, Kanye, Botswana.

${ }^{2}$ Mrs. Fungai Mthombeni is a Lecturer in Family and Consumer Sciences at the University of Botswana, Private Bag 0022, Gaborone, Botswana.

${ }^{2}$ Dr. José Jackson is a Food Scientist in the Centre for Scientific Research, Indigenous Knowledge and Innovation (CesrIKi), University of Botswana, Gaborone, Botswana. 


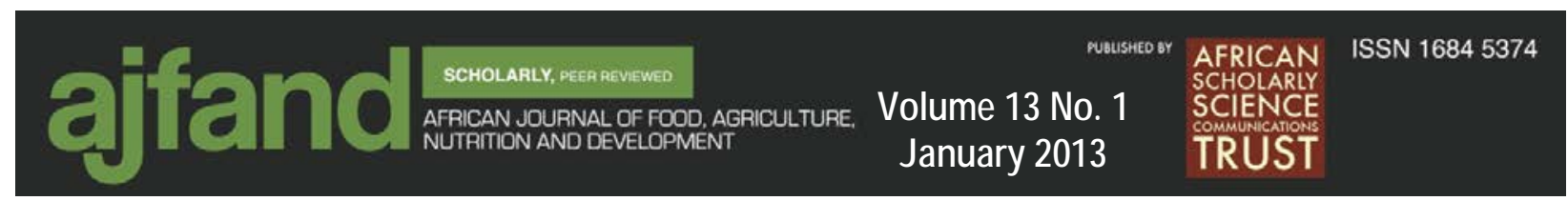

\section{ABSTRACT}

Morama bean (Tylosema esculentum) is an indigenous bean of the Kalahari region of Botswana. It has high nutritional content and is believed to also contain high levels of phytonutrients. The bean is traditionally eaten roasted as a snack but there is increasing emphasis to develop other innovative high value morama products, while maintaining its healthful properties. The effect of pre-processing treatments including salt-water-blanching, sodium-bicarbonate-blanching, hot-water-blanching on the proximate composition, total solids non-fat, colour, viscosity, sediments, $\mathrm{pH}$ and titratable acidity of morama milk was assessed. Consumer preference of the morama milk was also studied, using a soymilk control. Milk extracts were stored at $4^{\circ} \mathrm{C}$ for up to 24 hours and analyses conducted using standard methods. The findings indicated that the pre-processing treatments produced significant differences $(\mathrm{p}<$ $0.05)$ in protein $(1.50 \pm 0.18 \mathrm{~g} / 100 \mathrm{~g})$ and carbohydrate $(1.09 \pm 0.94 \mathrm{~g} / 100 \mathrm{~g})$ composition of the baking soda blanched milk sample. The viscosity of the baking soda blanched milk (18.91 \pm 3.38cps) was significantly higher than that of the other milk samples, while the sediments of the salt water blanched milk $(14.01 \pm 1.63 \%)$ was significantly higher $(\mathrm{p}<0.05)$ than the others. Baking soda blanching resulted in the highest $\mathrm{pH}(7.31 \pm 0.32)$ and lowest titratable acidity levels $(0.45 \pm 0.24)$. The hot water blanched and baking soda blanched samples were slightly darker in colour, while the baking soda blanched sample had more greenness and less yellowness characteristics than the other two samples. Baking soda blanched pre-treated morama milk was the preferred morama milk by over $85 \%$ of the consumers; they also preferred it over soymilk. This is the first reported study on the processing of morama beans into milk and it demonstrated that it was possible to process high quality and acceptable morama milk, which can be utilized as a supplement to the dairy industry.

Key words: morama, milk, physico-chemical, sensory, nutrition 


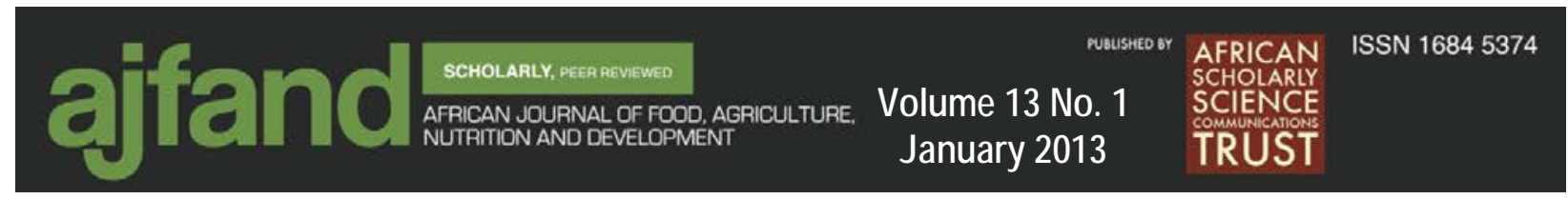

\section{INTRODUCTION}

Morama bean (Tylosema esculentum) is a wild, hardy perennial leguminous oilseed endemic to Southern Africa, including Botswana, Namibia and South Africa [1]. In Botswana the bean is referred to as morama, while in other countries like Namibia and South Africa it is referred to as marama. A number of studies have looked at the seed's nutritional composition and characterisation [2-5]. The edible seeds contain 30$39 \%$ protein of large lysine and relatively large S-amino acid content, oil of 35-43\%, which has a large proportion of oleic (49\%) and linoleic acid (24\%) and carbohydrate of $18-25 \%$ [3]. Morama is also a good source of micronutrients such as calcium (42 $\mathrm{g} / 100 \mathrm{~g}$ ), iron (400 mg/100g), zinc (1000 mg/100g), phosphorus (67 g/100g), and magnesium (58 g/100g) [3]. It compares well with the soybean (37\% and 19\%) and peanut (24\% and $42 \%)$ in terms of its protein and oil content, respectively [3].

There is increasing scientific consensus that eating more plant foods but fewer animal foods would best to promote health [6]. Oxidative stress associated with respiration of energy has been described as a factor in the etiology of dietary diseases, such as cardiovascular disease and cancer, and in aging [6,7]. Evolutionary trends such as increased ingestion of long-chain polyunsaturated fatty acids and cholesterol, heating of fatty foods and greater longevity increased oxidative stress; conversely, greater reliance on animal foods and less on plants decreased ingestion of exogenous antioxidants [7]. Plant milks offer individuals who are lactose-intolerant, and/or simply health-conscious (for example, those seeking to consume cholesterol-free products), with healthy alternatives. Such products can be made from plant materials across a diverse range of categories, including beans, nuts and grains, for example soy milk, peanut milk, and rice milk, respectively [8-14].

There has been little reported research that studied comprehensively the utilisation of the morama bean. As reported by Iwuoha and Umunnakwe, production of liquid bean milks like soybean milk generally involves a blanching and roasting pre-treatment, dehulling, milling, suspending in water, boiling, and filtration to obtain a milk-like phase [8]. Blanching and roasting techniques are believed to improve the flavour by removing the bitter or beany flavour components of soybean and aid in the development of desirable nutty flavour components [8]. Morama milk was therefore produced as the aqueous extract of morama beans, using a Soy $\operatorname{Cow}^{\mathrm{R}}$, which is a small-scale processing equipment that is customarily used for soybeans processing into milk [15]. The pre-processing treatments were selected to decrease the bitterness characteristics in morama milk and aid in desirable flavor components as well as to reduce the fat content to make it into a healthier alternative. The objective was to evaluate the effect of various pre-processing treatments on the physico-chemical properties and consumer preference of morama milk.

\section{METHODOLOGY}

\section{Plant material}

Clean, whole morama beans from the 2006 harvest year were used in the study (Figure 1). The beans were stored in covered plastic buckets in the pilot plant of the 


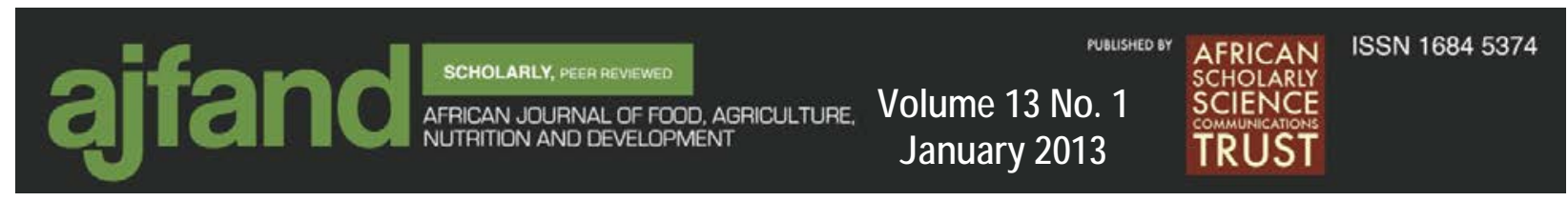

National Food Technology Research Centre (NFTRC), Kanye, Botswana and kept at $28-30^{\circ} \mathrm{C}$ until further analyses.
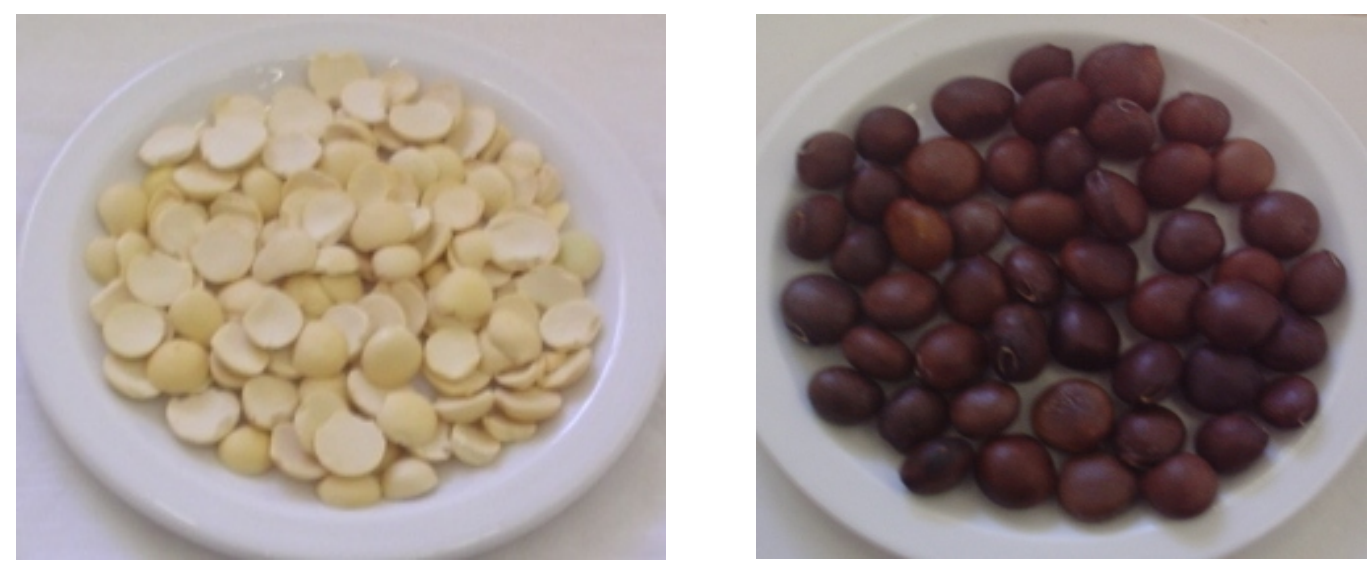

Figure 1: Shelled and unshelled morama bean seeds

\section{Morama milk processing}

Morama beans were cracked manually then pre-processed using the blanching pretreatments indicated in Figure 2. The blanched beans were ground and pressurecooked in a SoyCow ${ }^{\circledR}$ (Malnutrition Matters, Ottawa, Canada) at $98^{\circ} \mathrm{C}$ for 3 minutes to form a slurry, which was filtered successively through $475 \mu \mathrm{m}$ and $180 \mu \mathrm{m}$ sieves. The milk was heated at $98^{\circ} \mathrm{C}$ for 2 minutes and homogenized at 4000 psi. It was then bottled and pasteurized at $63^{\circ} \mathrm{C}$ for 30 minutes in a 5L-capacity Armfield multipurpose processor (Ringwood, UK), cooled then refrigerated at $4^{\circ} \mathrm{C}$ until further analyses. The acceptability of all eight samples was assessed by an in-house trained panel and those that were considered unacceptable were eliminated from further analyses. Three processing trials of each blanching pre-treatment were done and the samples were analyzed in triplicate.

Pre-treatment 1: Blanched soaked beans (PT1) - Shelled morama beans (150 g) were soaked for 6 hours in water at room temperature at a bean: water ratio of 1:7. The water was drained off and the beans were then blanched at $98^{\circ} \mathrm{C}$ for 15 minutes.

Pre-treatment 2: Roasted shelled beans (PT2) - Shelled Morama beans (150 g) were roasted in an oven at a temperature of $140^{\circ} \mathrm{C}$ for 30 minutes.

Pre-treatment 3: Roasted unshelled beans (PT3) - Unshelled Morama beans (150 g) were roasted in an oven at a temperature of $140^{\circ} \mathrm{C}$ for 20 minutes; the roasted beans were then shelled manually.

Pre-treatment 4: Hot water blanched rinsed beans (PT4) - Shelled morama beans $(150 \mathrm{~g})$ were blanched three times in $1000 \mathrm{ml}$ water at $98^{\circ} \mathrm{C}$ for 5 minutes. The blanching solution was drained and the beans were rinsed with hot water. 


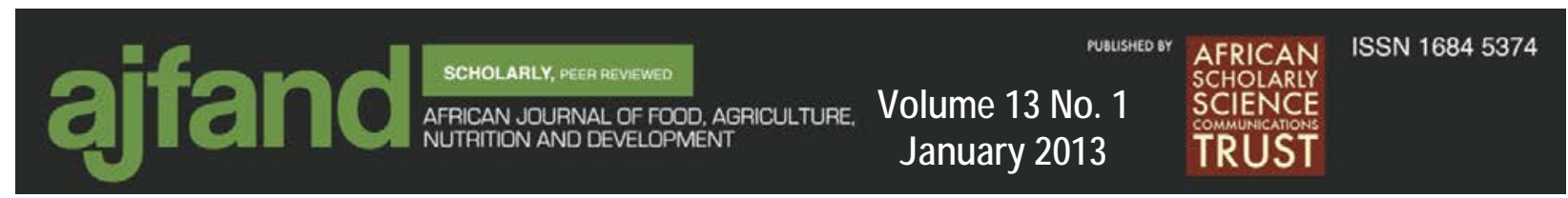

Pre-treatment 5: Baking-soda-blanched beans (PT5) - Shelled morama beans (150 g) were blanched three times in a $1000 \mathrm{ml}$ baking soda solution $(0.25 \%$ of blanch water by weight) at $98^{\circ} \mathrm{C}$ for 5 minutes. The blanching solution was drained and the beans were rinsed with hot water.

Pre-treatment 6: Salt-water-blanched beans (PT6) - Shelled morama beans (150 g) were blanched three times in a $1000 \mathrm{ml}$ salt water solution $(0.25 \%$ of blanch water by weight) at $98^{\circ} \mathrm{C}$ for 5 minutes. The blanching solution was drained and the beans were rinsed with hot water.

Pre-treatment 7: Unblanched soaked beans (PT7) - Shelled morama beans (150 g) were soaked in water at room temperature for 6 h using a 1:10 bean: water ratio.

Pre-treatment 8: Defatted shelled beans (PT8) - Shelled morama beans (150 g) were milled in a hammer mill to pass through a sieve with $3 \mathrm{~mm}$ pore size to produce the full fat morama meal.

Samples of the meal (100 g) were then defatted by stirring in $300 \mathrm{ml}$ of food grade ethanol for $30 \mathrm{~min}$. The mixture was allowed to decant after which the solvent layer was drained off. The extraction was repeated twice to achieve maximum defatting. After defatting, the mixture was filtered, rinsed with fresh solvent and then left overnight to dry at room temperature. Residual fat content was determined after each extraction. 


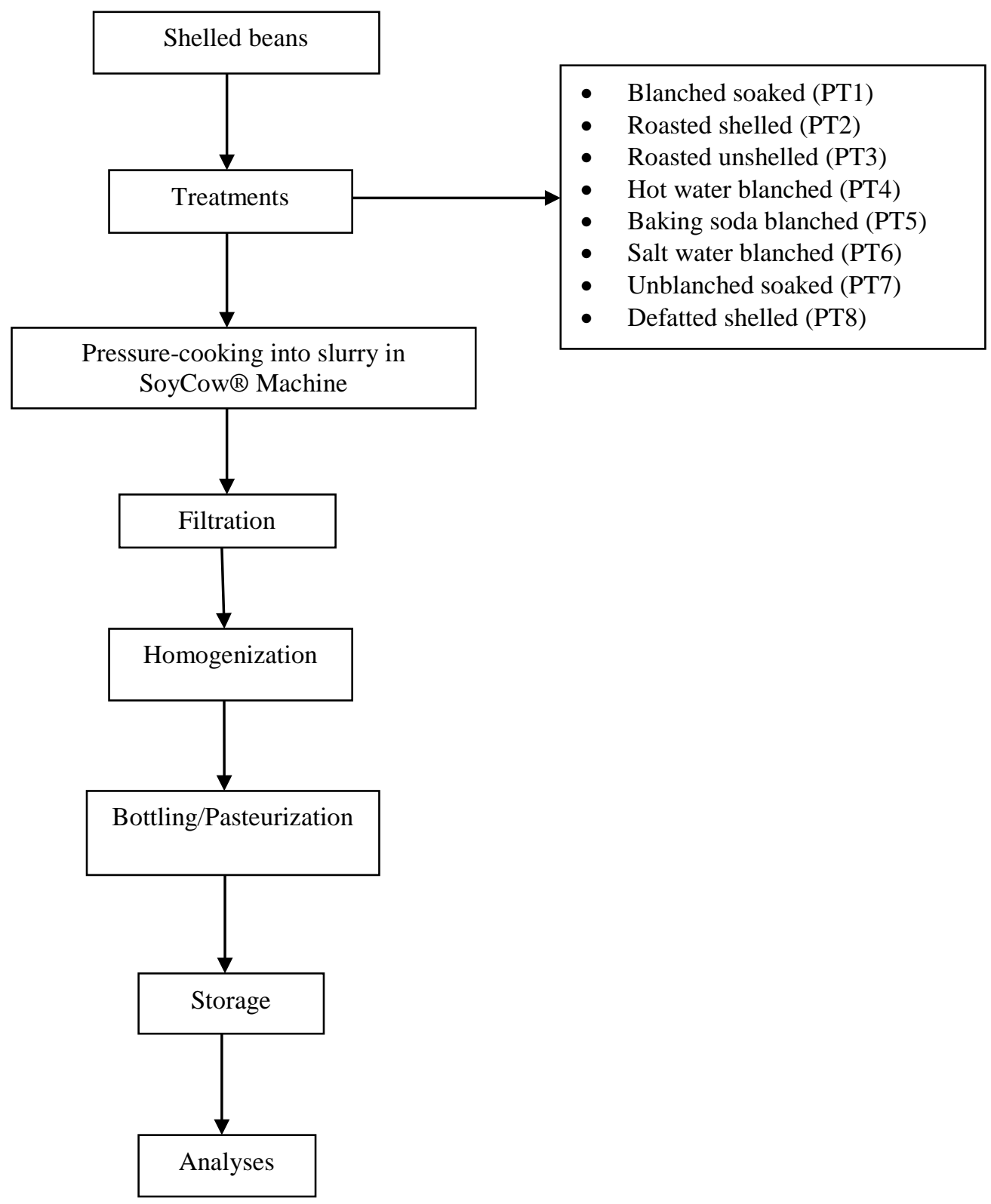

Figure 2: Schematic of processing of morama milk 


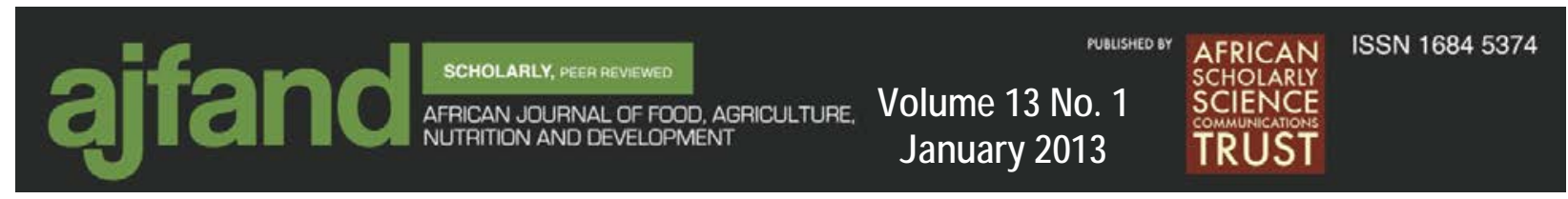

\section{Physico-chemical composition of morama milk}

Proximate composition including fat, protein, ash, crude fiber and moisture was analyzed using standard AOAC methods [16]. The carbohydrate content was determined by difference (carbohydrate $=100-$ [protein + fat + moisture + ash $]$ ), the energy value was calculated $\left(9 \mathrm{kcal} \mathrm{g}^{-1}\right.$ milk x g fat $+4 \mathrm{kcal} \mathrm{g}^{-1}$ milk x g protein +4 $\mathrm{kcal} \mathrm{g}^{-1}$ milk $\mathrm{x}$ g carbohydrate) as well as the total solids (100 $\mathrm{g}-$ [moisture content]).

The colour of the milk from different treatments was measured using a Hunter Lab Scan XE colorimeter (Hunter Associates Laboratory, Inc., Reston, VA, USA) in terms of $\mathrm{L}, a, b$, values. A glass petri dish containing $20 \mathrm{ml}$ of morama milk was placed above the light source and covered, and Hunter L, $a$, and $b$ values recorded. Morama milk viscosity was obtained between $20^{\circ} \mathrm{C}$ and $30^{\circ} \mathrm{C}$, using a Brookfield DV-1+ viscometer (Brookfield Engineering Laboratories, Inc., Massachusetts, USA). The sediments in the milk were analyzed using a centrifuge PK131 (ALC International, Italy) at a speed of $2700 \mathrm{rpm}$ for 10 minutes. The supernatants were removed and sediments were measured. The $\mathrm{pH}$ was measured using Denver Instrument model-250 $\mathrm{pH} / \mathrm{mV} / \mathrm{ISE}$ meter (Denver Instrument, Denver, Colorado). The titratable acidity of diluted milk was determined by titrating with $0.1 \mathrm{~N}$ sodium hydroxide $(\mathrm{NaOH})$, using a few drops of $1 \%$ phenolphthalein solution as indicator [17].

\section{Microbiological profile during storage}

Standard procedures for the microbiological examination of foods was used to analyze for aerobic plate count (Plate Count Agar), total coliforms including E. Coli (3M E. Coli / Coliform Petrifilm), S. aureus ((Baird-Parker Agar with EY Tellurite Enrichment), yeast and molds (Potato Dextrose Agar) and lactic acid bacteria (deMann Regosa Sharpe Agar) [18]. Analysis was conducted in duplicate at 3-day intervals over a 10 day period at the National Food Technology Research Centre, Kanye, Botswana. The milk had been refrigerated at $4^{\circ} \mathrm{C}$.

\section{Sensory evaluation of morama milk}

Two sites were selected for sensory evaluation. One site was a central location on the campus of the University of Botswana in Gaborone, the capital city. The second site was a central location in Kanye, an urban village in the south of Botswana where the milk was processed. As per guidelines of the Ministry of Health Ethics Committee of Botswana, evaluation of food for the purpose of tasting was exempt from review.

Consumers were recruited using advertisements of morama milk sensory testing and only individuals that indicated a liking for milk products were allowed to participate. In addition, persons who had allergies to peanuts were advised not to participate. One hundred and sixty three consumers participated in the sensory testing and received verbal information about the morama bean, its nutritional value and a brief overview of the objective of the study. Four milk samples were used for consumer testing, three morama milk samples and a commercial sample of soymilk, which were presented in 8-oz sample cups with 3-digit codes and served at room temperature. Each consumer was required to assess the appearance, aroma, taste, viscosity and overall preference using a paired comparison test [19].

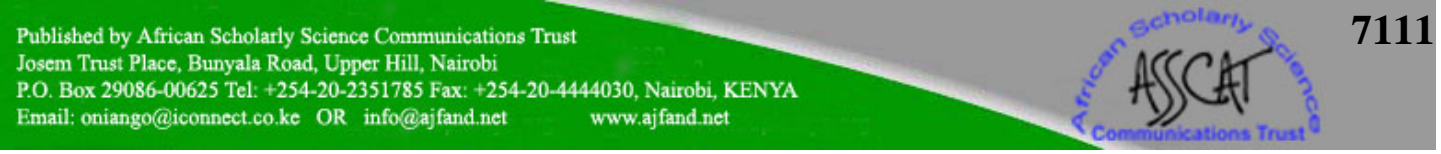




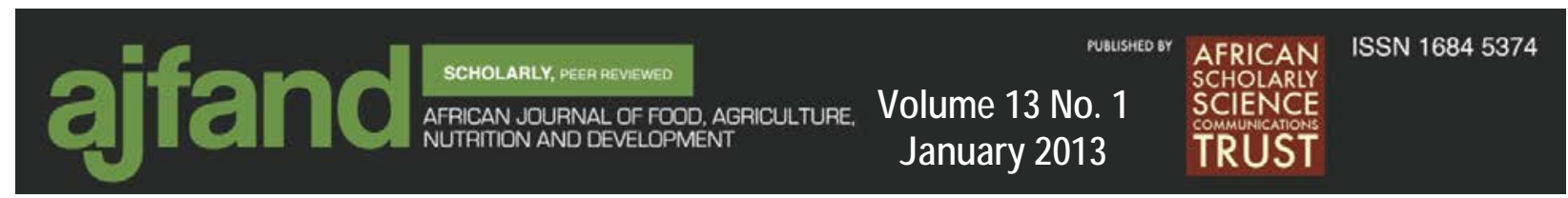

\section{Statistical analysis}

The effects of the pre-processing treatments on the physico-chemical attributes of the morama milk was evaluated using analysis of variance (ANOVA) based on a 5\% level of significance in SPSS Version 15 (SPSS Inc, Chicago, IL USA). The consumer sensory results were analysed using BINOMDIST in MS Excel (Microsoft, Seattle, WA USA). Significant differences between means were determined using Fisher's least significant difference (LSD) test.

\section{RESULTS}

An average of $150 \mathrm{~g}$ of morama bean seeds that was used for each pre-treatment produced approximately $450 \mathrm{ml}$ of morama milk, thus achieving a yield of about $3 \mathrm{~L}$ milk kg-1 seed, which is comparable with other reported studies on liquid bean milks $[8,15]$. Of the eight pre-treated milk samples, five of them including the blanched soaked (PT1), roasted shelled (PT2), roasted unshelled (PT3), unblanched soaked (PT7) and the defatted shelled (PT8) samples were eliminated by the in-house sensory evaluation panel for further analyses. The samples were considered too watery, too dark, too bitter or were not creamy enough. The three pre-treatments that were used for further analyses included hot water blanched (PT4), baking soda blanched (PT5), and salt water blanched (PT6).

\section{Physico-chemical properties of morama milk}

The proximate composition of hot water blanched (PT4), baking soda blanched (PT5) and salt water blanched (PT6) morama milk compared with commercial soybean milk is indicated in Table 1 . There were no significant differences in the composition between the different pre-treatments for all the nutrients analyzed except for protein and carbohydrate content. The baking soda blanched (PT5) pre-treatment had significantly higher levels of carbohydrate and lower levels of protein than the other two pre-treatments $(\mathrm{p}<0.05)$. Low ash content was obtained from morama milk that involved blanching pre-treatments (PT4 and PT6) compared with that blanched in baking soda (PT5). However, compared to the commercial soybean milk, the proximate composition of morama milk was significantly different $(p<0.05)$. Morama milk had almost twice the amount of fat and fiber compared with soybean milk, while soybean milk had more ash, protein and carbohydrate. The exception to this was the energy value, for the morama milk samples, which ranged between 37.93 - $39.36 \mathrm{kcal}$, and was comparable with $39.1 \mathrm{kcal}$ reported for soy milk [20].

Figure 3 shows the colour characteristics of morama milk samples after different preprocessing treatments. It indicated that there were no significant differences in the colour characteristics of the three samples. The $L$-value ranged from $81.2-82.5$ and suggests that all of the samples were light in colour. The $a$-value ranged from -0.86 - 1.19 which indicated that all three had more greenness characteristics. The $b$-value ranged from 13.9 - 15.1 and suggests that the milk samples had yellowness characteristics. These findings corroborate the visual appearance of the milk which had a chalky white appearance like dairy milk. 


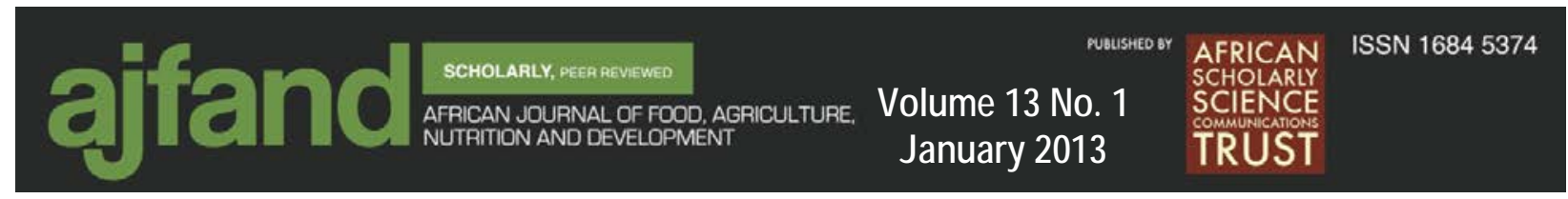

The sedimentation, viscosity, and solids of morama milk samples are shown in Table 2. It indicated that there were no significant differences $(p<0.05)$ in the total solids and the total solids-non fat between the samples. The baking soda blanched sample (PT5) had a significantly higher viscosity compared to the other two samples and the sedimentation of the salt water blanched sample (PT6) was higher than the others (p < $0.05)$. The titratable acidity and $\mathrm{pH}$ of the pre-treated morama milks are also shown in Table 2 and indicate that they are influenced by the pre-processing treatment used. The $\mathrm{pH}$ of the salt water blanched (PT6), hot water blanched (PT4) and baking soda blanched (PT5) samples ranged from 6.83 - 7.31, respectively and indicated slight differences between the salt water blanched sample compared to the others. The acidity ranged from $0.45-0.65$ and indicated no differences between the samples.

\section{Microbiological profile}

The microbiological profile of the pre-treated morama milk samples up to 10 days after processing and storage at refrigerated temperature indicated that the numbers of microorganisms detected in the morama milk samples were below the limits according to standards available for soy milk [20]. The total number of aerobic bacteria after 3 days and 10 days was $<25 \mathrm{cfu} \mathrm{ml}^{-1}$ and lactic acid bacteria, yeast and

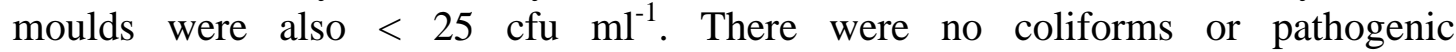
microorganisms such as E. coli and S. aureus detected in any of the samples after 10 days. These findings suggested that the morama milk samples did not have any pre- or post-processing contamination that could cause spoilage or lead to illness of consumers even after 10 days.

\section{Consumer sensory evaluation of morama milk}

Two morama milk samples including salt water blanched (PT6) and baking soda blanched (PT5) pre-treatments were used in the consumer sensory evaluation because of their appearance and reported nutty aroma and flavour attributes and also because they had less salty, bitter and chalky characteristics compared to the other sample [21]. Sixty one adult consumers evaluated the morama milk samples in Kanye, an urban village in Botswana; while 102 consumers evaluated the samples in Gaborone, the capital of Botswana. In the two locations, the sensory attributes of the salt water blanched (PT6) and baking soda blanched (PT5) pre-treated morama milk samples were unanimously preferred over soy milk by consumers. The two morama milk samples were also tested against each other and the baking soda blanched (PT5) pretreated morama milk was significantly preferred $(\mathrm{p}<0.05)$ over the salt water blanched (PT6) sample.

\section{DISCUSSION}

This study investigated processing of the wild indigenous morama bean into milk and of evaluating the effect of different pre-processing treatments on the physico-chemical quality of the milk. The findings suggest that overall high quality morama milk could be processed which could be safely stored refrigerated for up to 10 days. In addition, milk processed using a baking soda blanching pre-treatment was preferred by consumers over other pre-treatments and also over soymilk. 


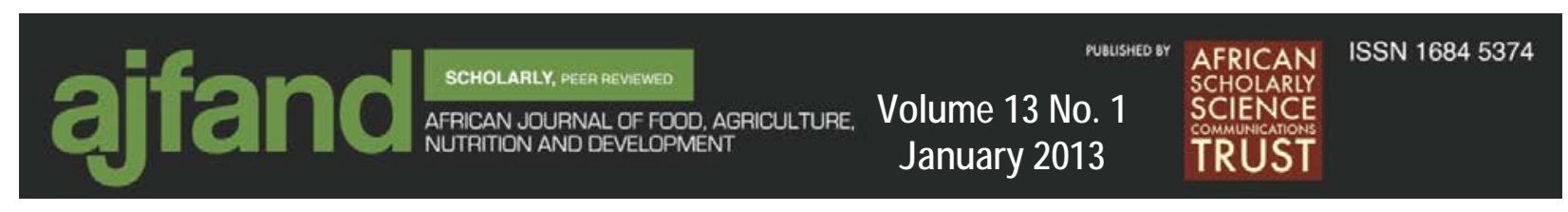

Previous studies on processing of soymilk also reported on changes in the protein and carbohydrate content $[8,22]$. Protein changes were reported to occur between heated and unheated samples as well as those blanched in bicarbonate soda. Carbohydrate changes occurred between dry dehulled versus wet dehulled samples and blanching in bicarbonate soda [8,22]. All of the samples in this study involved a blanching pretreatment so protein denaturation should have occurred similarly in all samples. However, protein and soluble carbohydrate leaching into the blanching water, particularly in the bicarbonate soda blanch is likely responsible for the differences in the total protein and carbohydrate content observed in morama milk. In the study reported by Ku et al. tap water-blanched, milled and homogenized beans and the final beverage contained slightly higher protein and carbohydrate concentrations than the corresponding bicarbonate treated samples [22]. 

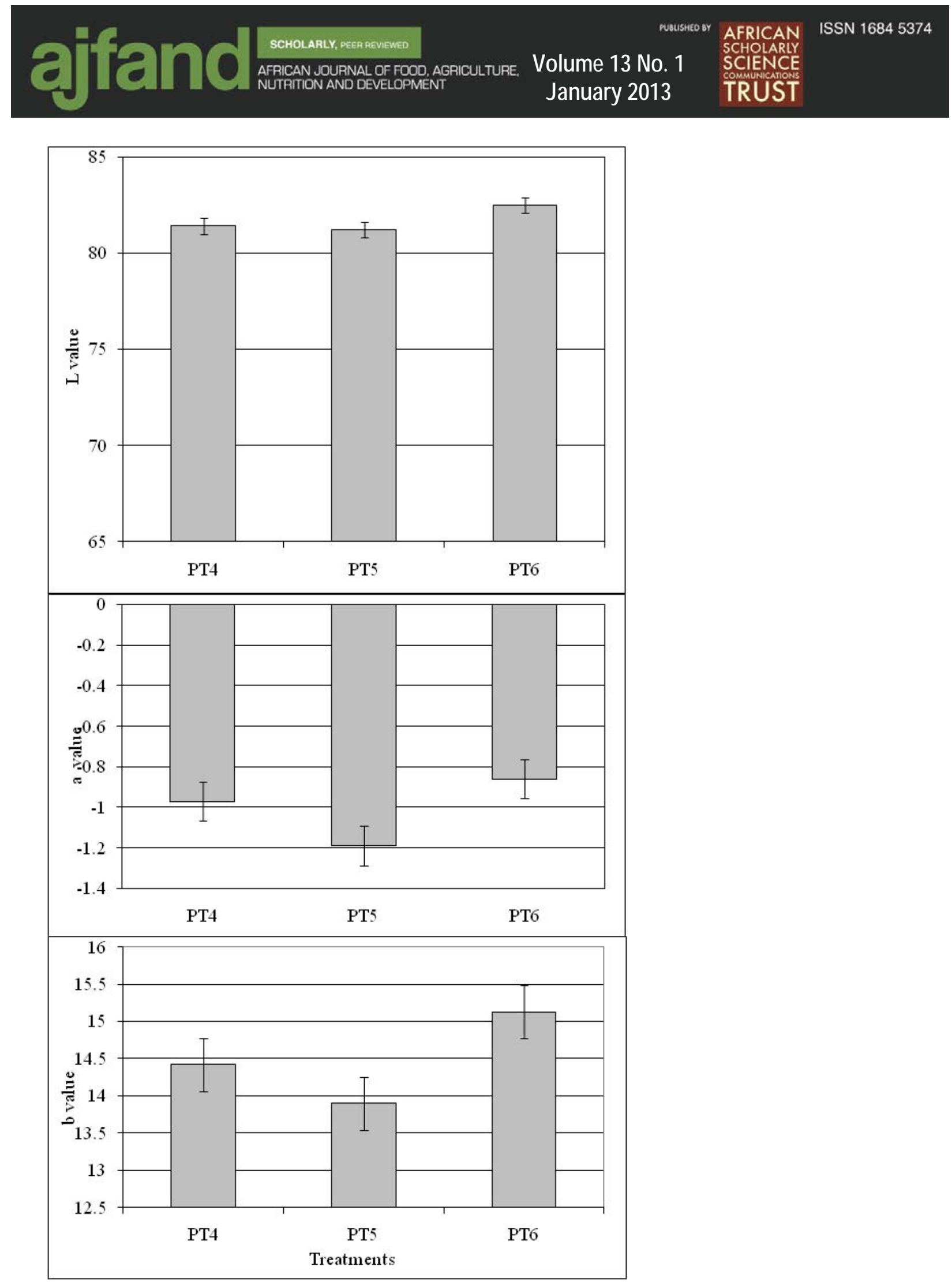

Figure 3: Color characteristics of hot water blanched (PT4), baking soda blanched (PT5) and salt water blanched (PT6) pre-processed morama milk ( $L$ value is a measure of lightness, with 0 = black and 100 = white; a-value is a measure of redness, with $+a=$ redness and $-\mathbf{a}=$ greenness; $b$-value is a measure of yellowness, with $+b=$ yellowness, $-b=$ blueness $)$. 


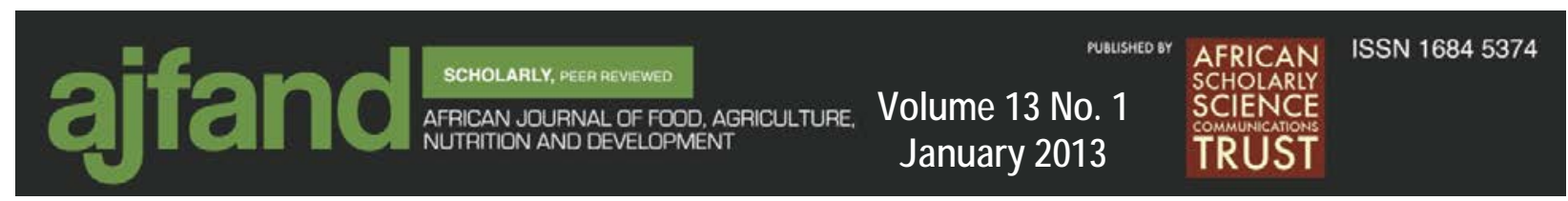

In terms of the ash content, although there were no significant differences observed, the addition of sodium bicarbonate in the blanching water resulted in a slight increase in ash content. This may be likely due to an increase in the sodium content as a result of the sodium bicarbonate pre-processing of the beans. This has been reported previously for soymilk $[8,22]$. The proximate composition of the morama milk samples was however significantly different to that of soymilk. It must be noted that the soybean and the morama bean milk samples were not processed similarly, therefore this could account for the compositional differences observed.

The viscosity and sedimentation appeared to be affected by the pre-processing method. This has been reported in other studies with soybean milk where viscosity changed with pre-processing and was likely to be influenced by the denaturation of the morama proteins and the amount, nature and dispersion of solids present in the milk $[8,23]$. The $\mathrm{pH}$ of the salt water blanched (PT6), hot water blanched (PT4) and baking soda blanched (PT5) samples increased from slightly acidic to alkaline, respectively. This was expected because of the presence of the acidic chloride anion in the salt water blanch and the alkaline bicarbonate anion in the baking soda blanch pre-treatments.

The use of sodium carbonate and bicarbonate in the processing of soy beans into soymilk to reduce undesirable flavours has been reported in earlier studies in the literature [22,24,25]. In addition, other studies by Kuntz et al. showed that bicarbonate-blanched soy beverages were less chalky, had less mouth drying and significantly better flavor than the comparable water-blanched product $[26,27]$. These earlier findings for soy milk have been corroborated in this study for morama milk.

\section{CONCLUSION}

The data presented suggest that high quality morama bean milk could be processed at small-scale level using a SoyCow ${ }^{\circledR}$. The process consisted of blanching in $0.25 \mathrm{~g}$ bicarbonate soda $100 / \mathrm{g}$, pressure cooking in a SoyCow ${ }^{\circledR}$ at $98^{\circ} \mathrm{C}$ for 3 minutes, homogenization at $4000 \mathrm{psi}$, bottling, pasteurization at $63^{\circ} \mathrm{C}$ for 30 minutes, cooling then refrigeration at $4^{\circ} \mathrm{C}$. The SoyCow ${ }^{\circledR}$ technology has been demonstrated previously in the small-scale processing of soymilk. Pre-treating morama beans with a 0.25 g bicarbonate soda 100/g blanch produced the best physico-chemical properties of morama milk. Consumers preferred the baking soda blanched pre-treated morama milk over other samples; they also preferred it over a commercially available soymilk.

In Botswana, soymilk is consumed mostly by infants and children with allergy or intolerance to cow's milk while adult consumption is mostly due to a vegetarian lifestyle. The commercial processing of milk from a legume indigenous to Africa offers great potential for improving livelihoods in communities where the bean is found. Further research is required on the micronutrient composition and the role that sensory attributes may have in consumer acceptability of the milk. These findings reported in this study provide preliminary evidence of the potential of morama milk as a supplement to the dairy industry. 


\section{ACKNOWLEDGEMENTS}

This study was sponsored by the MARAMA II Project EU FP6 Contract No. 032059

(Development of Innovative and Healthful Morama Bean (Tylosema esculentum) Products Targeting Niche Markets). Appreciation is extended to the Research Assistants Ms. Monica Sopejame, Ms. Tsholofelo Moatshe and Mr. Kabo Masisi for their assistance with the experiments. 
Table 1: Proximate composition of morama bean milk from different preprocessing treatments compared with commercial soybean milk

\begin{tabular}{|c|c|c|c|c|c|c|c|}
\hline \multirow{2}{*}{$\begin{array}{l}\text { Pre- } \\
\text { processing } \\
\text { treatment }\end{array}$} & \multicolumn{7}{|c|}{ Nutrients } \\
\hline & $\begin{array}{c}\text { Fat } \\
\text { (g/100g) }\end{array}$ & $\begin{array}{l}\text { Protein } \\
\text { (g/100g) }\end{array}$ & $\begin{array}{c}\text { Ash } \\
(\mathrm{g} / 100 \mathrm{~g})\end{array}$ & $\begin{array}{c}\text { Fiber } \\
\text { (g/100g) }\end{array}$ & $\begin{array}{l}\text { Moisture } \\
\text { (g/100g) }\end{array}$ & $\begin{array}{l}\text { Carbohydrate§ } \\
\text { (g/100g) }\end{array}$ & $\begin{array}{c}\text { Energy } ¥ \\
\text { (kcal) }\end{array}$ \\
\hline $\begin{array}{l}\text { Hot water } \\
\text { blanched }\end{array}$ & $\begin{array}{c}3.15 \pm \\
0.47^{\mathrm{a}}\end{array}$ & $\begin{array}{c}2.00 \pm \\
0.10^{\mathrm{a}}\end{array}$ & $\begin{array}{l}.16 \pm \\
0.03^{\mathrm{a}}\end{array}$ & $\begin{array}{l}.53 \pm \\
0.14^{\mathrm{a}}\end{array}$ & $\begin{array}{c}94.04 \pm \\
0.88^{\mathrm{a}}\end{array}$ & $.63 \pm 0.42^{\mathrm{a}}$ & $\begin{array}{c}38.96 \pm \\
5.77 a\end{array}$ \\
\hline $\begin{array}{l}\text { Baking soda } \\
\text { blanched }\end{array}$ & $\begin{array}{c}3.06 \pm \\
0.45^{\mathrm{a}}\end{array}$ & $\begin{array}{c}1.50 \pm \\
0.18^{\mathrm{b}}\end{array}$ & $\begin{array}{l}.19 \pm \\
0.04^{\mathrm{a}}\end{array}$ & $\begin{array}{l}.40 \pm \\
0.21^{\mathrm{a}}\end{array}$ & $\begin{array}{c}94.14 \pm \\
0.89^{\mathrm{a}}\end{array}$ & $1.09 \pm 0.94^{b}$ & $\begin{array}{c}37.93 \pm \\
4.31^{\mathrm{a}}\end{array}$ \\
\hline $\begin{array}{l}\text { Salt water } \\
\text { blanched }\end{array}$ & $\begin{array}{c}3.26 \pm \\
0.55^{\mathrm{a}}\end{array}$ & $\begin{array}{l}1.93 \pm \\
0.26^{\mathrm{a}}\end{array}$ & $\begin{array}{l}.16 \pm \\
0.02^{\mathrm{a}}\end{array}$ & $\begin{array}{l}.53 \pm \\
0.22^{\mathrm{a}}\end{array}$ & $\begin{array}{c}94.07 \pm \\
0.71^{\mathrm{a}}\end{array}$ & $.55 \pm 0.67^{\mathrm{a}}$ & $\begin{array}{c}39.36 \pm \\
4.68^{\mathrm{a}}\end{array}$ \\
\hline Soybean milk & $1.82^{\mathrm{b}}$ & $3.07^{\mathrm{C}}$ & $0.9^{\mathrm{b}}$ & $0.28^{\mathrm{b}}$ & $91.6^{\mathrm{b}}$ & $2.61^{\mathrm{c}}$ & $39.1^{\mathrm{a}}$ \\
\hline
\end{tabular}

Table 2: Other physical and chemical properties of pre-processed morama bean milk

\begin{tabular}{lcccccc}
\hline $\begin{array}{l}\text { Pre-processing } \\
\text { treatment }\end{array}$ & $\begin{array}{c}\text { Total } \\
\text { solids } \\
(\mathrm{g} / 100 \\
\mathrm{g})\end{array}$ & $\begin{array}{c}\text { Total } \\
\text { solids non- } \\
\text { fat }(\mathrm{g})\end{array}$ & $\begin{array}{c}\text { Viscosity } \\
(\mathrm{cps})\end{array}$ & $\begin{array}{c}\text { Sedimentation } \\
(\%)\end{array}$ & $\mathrm{pH}$ & $\begin{array}{c}\text { Titratable } \\
\text { acidity } \\
(\%)\end{array}$ \\
\hline Hot water & $5.95 \pm$ & $2.80^{\mathrm{a}}$ & $13.71 \pm$ & $12.04 \pm 1.88^{\mathrm{a}}$ & $7.05 \pm$ & $0.65 \pm$ \\
blanched & $0.88^{\mathrm{a}}$ & & $1.70^{\mathrm{a}}$ & & $0.32^{\mathrm{a}, \mathrm{b}}$ & $0.34^{\mathrm{a}}$ \\
Baking soda & $5.85 \pm$ & $2.79^{\mathrm{a}}$ & $18.91 \pm$ & $12.01 \pm 2.09^{\mathrm{a}}$ & $7.31 \pm$ & $0.45 \pm$ \\
blanched & $0.89^{\mathrm{a}}$ & & $3.38^{\mathrm{b}}$ & & $0.32^{\mathrm{b}}$ & $0.24^{\mathrm{a}}$ \\
Salt water & $5.92 \pm$ & $2.66^{\mathrm{a}}$ & $12.82 \pm$ & $14.01 \pm 1.63^{\mathrm{b}}$ & $6.83 \pm$ & $0.58 \pm$ \\
blanched & $0.71^{\mathrm{a}}$ & & $1.57^{\mathrm{a}}$ & & $0.63^{\mathrm{a}}$ & $0.34^{\mathrm{a}}$ \\
\hline
\end{tabular}

${ }^{*}$ Different letters within a column for each physical property indicate significant differences at $(\mathrm{p}<$ $0.05)$. 


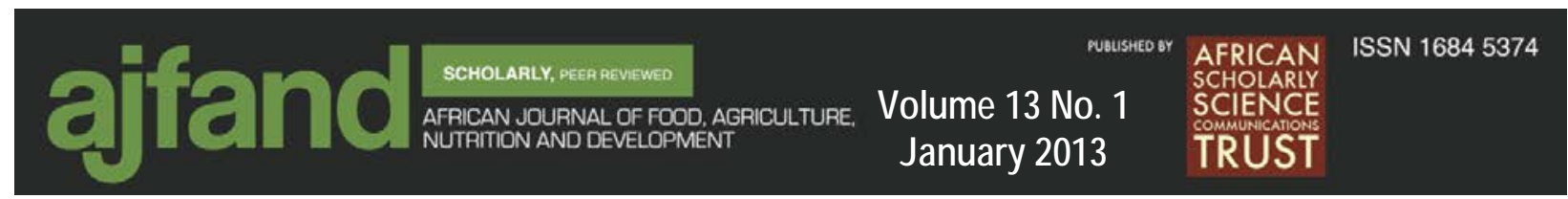

\section{REFERENCES}

1. Müseler DL, Schönfeldt HC, Kandawa-Schulz MA and A Rothauge Sensory profiles of the Botswana and Namibia Morama Bean (Tylosema esculentum). Paper presented at the $10^{\text {th }}$ Congress, Agricultural Society of Namibia, Windhoek, Namibia. 2003.

2. Wehmeyer AS Nutrient composition of some edible wild fruits found in the Transvaal. South African Med J. 1966; 40: 1102-1104.

3. Bower N, Hertel $\mathbf{K}, \mathbf{O h} \mathbf{J}$ and $\mathbf{R}$ Storey Nutritional evaluation of marama bean (Tylosema esculentum, Fabaceae): Analysis of the seed. Econ Bot. 1988; 42: $533-540$.

4. Ketshajwang KK, Holmback $\mathbf{J}$ and SO Yeboah Quality and compositional studies of some edible Leguminosae seed oils in Botswana. J Amer Oil Chem Soc. 1998; 75: 741-743.

5. Amarteifio JO and D Moholo The chemical composition of four legumes consumed in Botswana. J Food Comp Anal. 1998; 11: 329-332.

6. Nestle M Animal v. plant foods in human diets and health: Is the historical record unequivocal? Proc Nutr Soc. 1999; 58: 211-218.

7. Johns $\mathbf{T}$ The chemical ecology of human ingestive behaviours. Ann Rev Anthro. 1999; 28: 27-50.

8. Iwuoha CI and KE Umunnakwe Chemical, physical and sensory characteristics of soymilk as affected by processing method, temperature and duration of storage. J Food Chem. 1997; 59: 373 - 379.

9. Encarnacion SS and BO Rillo Improvement of quality characteristics of peanut milk. UP Home Econ J. 1982; 10: 43-61.

10. Guerra MJ, Gonzales D, Jaffé WG and M Calderon Formulation of a rice based drink with high nutritive value. Arch Latinoamer Nutr. 1981; 31: 337348.

11. Lin TC, Shao YY and $\mathbf{W}$ Chiang Investigation of the processing and the quality of rice milk. J Chin Agric Chem Soc. 1988; 26: 130-137.

12. Prabhavat S Production of rice milk. FAO Training Report on rice and rice products, Dakar, Senegal. 1989.

13. Yook C, Whang YH, Pek UH and KH Park Preparation of rice drink (shishae) by using starch hydrolyzing enzymes. Proc Intl Conf Biotech and Food. Doosan Res. Lab., Seoul, Korea Republic. 1990; 12-16. 


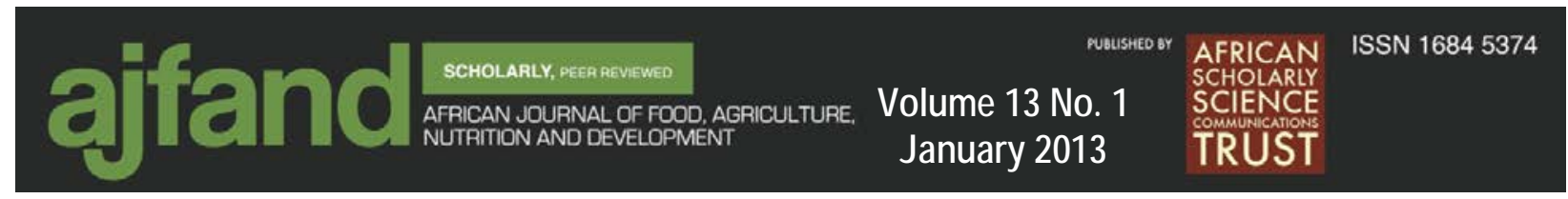

14. Lee $\mathbf{C}$ and LR Beuchat Chemical, physical and sensory characteristics of peanut milk as affected by processing conditions. J Food Sci. 1992; 57: 401405.

15. Daller F The Soy Cow: Small-Scale Soyfood Technology for MicroEnterprise and Nutrition. Report on Food Technology Solutions for India, Malnutrition Matters, Ottawa, Canada. 2005.

16. AOAC. (Association of Official Analytical Chemists), Official Methods of Analysis of the Association of Official Analytical Chemists, $17^{\text {th }}$ Ed. Washington, D.C. 2003.

17. Ranganna S Titratable acidity in fruit juices and beverages, in Handbook of analysis and quality control for fruit \& vegetable products, ed by S. Ranganna. McGraw Hill Education, London, UK. 1986; 868-870.

18. Downes FP and $\mathbf{K}$ Ito Compendium of Methods for the Microbiological Examination of Foods. American Public Health Association, Washington DC, $4^{\text {th }}$ Ed. 2001.

19. Meilgaard MC, Civille GV and BT Carr Sensory Evaluation Techniques, CRC Press, Taylor \& Francis Group, Boca Raton, Fl. 1999; 99-102.

20. Soyfoods Association of America. Voluntary standards for the composition and labeling of soymilk in the United States. 1996.

21. Tlhong T, Mthombeni F, Mpotokwane $\mathbf{S}$ and $\mathbf{J}$ Jackson Descriptive Sensory Evaluation of Morama Milk. Annual Report of MARAMA II Project, University of Botswana, Gaborone. 2009.

22. Ku S, Wei LS, Steinberg MP, Nelson AI and T Hymowitz Extraction of oligosaccharides during cooking of whole soybeans. J. Food Sci. 1976; 41: 361-364.

23. Liu Z $\mathbf{Z}$ and SKC Chang Soymilk viscosity as influenced by heating methods and soybean varieties. J Food Proc Pres. 2007; 31: 320-333.

24. Bourne MC, Escueta EE and $\mathbf{J}$ Banzon Effect of sodium alkalis and salts on pH and flavour of soymilk. J. Food Sci. 1976; 41: 62-66.

25. Khaleque A, Bannatyne WR and GM Wallace Studies on the processing and properties of soymilk: Effect of preprocessing conditions on the flavour and compositions of soymilks. J Sci Food Agric. 1970; 21: 579 - 583.

26. Kuntz DA Processing factors affecting the organoleptic quality of Illinois soy beverage. Ph.D. Thesis, University of Illinois, Champaign, IL. 1977. 
27. Badenhop AF and LR Hackler Effects of soaking soybeans in sodium hydroxide solution as pretreatment for soy milk production. Cereal Sci Today. 1970; 15: 84-88. 